\title{
Brazil: Military State and Vanishing Miracle
}

\section{Gabriel Bolaffi}

\section{Introduction}

When President Geisel was inaugurated in 1974, there were widespread hopes that Brazil would move toward less authoritarian rule. Geisel was not the choice of his predecessors, but succeeded in winning the nomination in spite of the opposition of the alliance between a particular army faction, public sector technocrats and entrepreneurs which had ruled the country since 1967 . Indeed, many Brazilians interpreted Geisel's success as a shift of the political spectrum back toward the liberal rhetoric that had inspired the 1964 coup d'état under Castelo Branco's leadership. Not only did Geisel in his inauguration speech make a firm commitment toward political softening, but many of the members of his personally chosen cabinet were old Castelo Branco style liberals. And by the end of Geisel's inauguration year, when Brazilians were called to vote at the first politically meaningful elections since 1964, the opposition won by what could only be regarded by Brazilian standards as an overwhelming landslide, and without causing any immediate visible hard-liner backlash.

By mid 1975, however, the cracks became visible in Geisel's political position. Detailed reports of the corruption of the previous Medici government were publicised, revealing that the new dealers needed to prove themselves better than their predecessors. And when a new wave of political arrests and tortures took place, culminating with the 'suicide' of a well-known and respected journalist Wlado Hertzog while detained at Sao Paulo's army headquarters, without the President being able to prevent it, one minister is said to have regarded it as "the beginning of the struggle between the SS and the Wehrmacht." Since then Geisel's support has eroded continuously. This process has culminated in the recent mini coup d'état when Geisel suspended the congress and altered the constitution by decree in order virtually to attempt to annihilate the opposition party.

\section{The historical context of Brazilian militarism}

It is difficult to explain the dilemmas in which the regime now finds itself without going back to the military's particular role in Brazil's history. The behaviour of the Brazilian army as an institution as well as the ideology of its leaders is difficult to explain in terms of the social extraction and recruitment of the officer corps. Instead, the crucial factor since the last decades of the 19th century in a fast growing and changing country such as Brazil has been the fact that the army was the only permanent and nationally inclusive institution where everything else was changing. The army was an institution devoted by definition to warfare and to the concept of the motherland, in a country that lacked both economic and political integration, being ruled by coffee barons in the region of Sao Paulo and Rio de Janeiro, by cattle caudilhos in the south, by sugar landlords in the coast of the north east and not ruled at all on something like 95 per cent of its territory. In the Brazil of 1900 , where almost any national institution or even the very concept of nation was a fiction, the army was a special kind of fiction.

The military then, clearly had to train its leaders for professional warfare. It sent them to Europe, where they learned the essential rules of the military game, including two which were destined to play a crucial far-reaching role. First, they learned that a modern army could not survive if it was prone to local and regional loyalties. Hence a pattern of periodic shifting of troop commanders through every region of the huge territory was introduced. Second, they learned that the fundamental conditions of successful warfare include industrial production and logistics. Thus by the early 1920 s the army had become a unique institution in that it alone contained a core of reasonably well-educated people with direct knowledge, both physical and social, of the country as a whole; who were ideologically committed to the inculcation of a sense of national identity; and were also committed to modernisation and industrialisation. These features became manifest in the mid 1920s through a series of military revolts (1922-24 and 1930$)^{1}$ known as Tenentismo (the lieutenants' movement). Although this movement was precipitated by several more immediate issues, it was essentially the result of a prise de conscience among young officers of the army's

1 The revolution of 1930 which led Getulis Vargas to powe: cannot be considered a Tenentista revolution. However, besides having been strongly influenced by the lieutenants, it also brought one of their facti-ns to power. 
modernising mission. ${ }^{2}$ From the 1920 s up to the $1940 \mathrm{~s}$ and $1950 \mathrm{~s}$, when the former lieutenants had become generals, they came in a sense to regard themselves as the nation's tutors.

From the nineteenth century the army had also begun to take on important economic responsibilies, including road building and the establishment of settlements in the previously almost unpopulated areas of the vast hinterland. During the present century, additional functions were assumed under the influence of Tenentismo. In the early 1930s the first air transport service, Correio Aereo Nacional, was created by the army. In 1933 army officers pressed President Getulio Vargas into passing a law giving the State control over hydro-electric and mineral resources. In the late 1930s when Vargas, who had become a dictator in 1937, was undecided between the Allies and the Axis but was leaning toward Hitler, the Americans succeeded in securing the Brazilian army's support, partly by promising to construct Brazil's first large steel mill at Volta Redonda, halfway between Sao Paulo and Rio de Janeiro. Moreover, the long national debate known as the Oil Campaign, which began in the late 1940s and led to the creation of Petrobras (the stateowned monopoly of oil drilling and refining) in 1954 was mainly inspired by nationalist sectors of the army:

Nationalism, of course, is by no means an exceptional or a peculiar feature of the Brazilian military. Their uniqueness lies rather in the strong managerial and technocratic character it developed. This emerged as a by-product of the belief-in the words of a saying common in Brazilian military circles-that they are the only force able to "lead their Homeland to the accomplishment of its historical destiny as a world power."

Needless to say, this missionary sentiment has always implied very ambiguous feelings toward civilians. The latter are regarded as intrinsically devoted to the egotistic pursuit of self-interest, corrupt, ignorant, incompetent and unable to lead the country toward its predestined role among the world powers. Nevertheless, civilians are after all also the essential raw material for the building of the Homeland. Their skills, such as expertise in industrial management, economic and financial affairs, cannot be dispensed with though they must

\footnotetext{
2 For a better account on Tenentismo, see V. Santa Rosa, 'O qu: foi o Tenentismo'. Boris Fausto in 'Pequenos ensqios de Historia da Republica' argues that the New Military School of $\mathrm{R}$ salengo, with its emphasis on training technical professionalised soldiers as opposed to the positivist orientated old 'Praia Vermelh?' School, was crucial for the shaping of the
} Tenentes gen sration. be exerted under military inspiration and surveillance.

In 1949 the National War College (ESG) was created in order to develop and transmit the knowledge necessary for the management of the nation and the planning of national security. As Regis de Castro Andrade points out, the ESG has never been a purely military institution, but more a centre for the elaboration of a political doctrine for both military and civilian elements. By 1960 it had graduated 200 higher civil servants, 39 members of parliament, 23 judges, 224 businessmen from industry and commerce, and 107 assorted professionals, such as lecturers, economists, writers, medical doctors and catholic clergy, a total of 693 civilians outweighing the 599 military graduates. 3

Andrade is certainly correct of course, when he relates the creation of the ESG to the Cold War context. But whatever the nature of the 'enemy' or the strictly military aspect of the soldiers' twin ideological prinicples of national security and development, they always regarded themselves as the civilians' tutors, and in spite of strong US and multinational influence never gave up their sense of mission regarding domestic affairs.

\section{The vanishing miracle}

When the soldiers took power in 1964 they had found a situation amounting to what would later be called stagflation, except that Brazil had it in elephantine doses: that is, a negative rate of economic growth associated with inflation at 87 per cent per annum. On the political scene, the similarity with events that have taken place in other Latin American countries, such as Uruguay and Chile, is far more more apparent than real. For better of for worse the Brazilian military did have a political and economic project for the country. This is not to say that they had a single, clearly defined political and economic model to impose on the country, nor that they were united under the same banner at any particular period of time, not even during the crucial months before and after the 1964 coup. But it does mean that it is an oversimplification to say that in overthrowing Goulart they merely played the role of a praetorian guard for local dominant classes and US economic interests.

I believe this helps to understand some of the many contradictions since the 1964 coup. While the rhetoric of those days was liberal and the slogan was that it was the civilians who had

3 See Regis de Castro Andrade, Brazil; the Military in Politics, Institute of Latin American Studies, University of Glasgow. 
called the army to intervene, both to fight communist subversion and to eliminate state economic intervention, the bourgeoisie soon realised that the outcome would differ from their expectations. On the political front the return to free elections and to civilan rule soon came to seem less remote only than the return of the Messiah. And as regards economic policy, by 1976 the stateowned sector accounted for over 60 per cent of capital formation.

The economic adventures and misadventures of the Brazilian military regimes since 1964 are wellknown and there is no need to outline them here: deflation and recession followed by booming economic growth that was, to a large extent, made possible by starvation levels of exploitation of the labour force and harsh political repression; then from 1974 inflation moving upwards again to reach 47 per cent in 1976.

When Geisel took over it was already clear that the miracle was vanishing. However, it is not possible to explain his abortive political new deal solely in terms of worsening economic conditions. The very fact that Geisel had succeeded in imposing himself as the army's Crown Prince as early as 1971 , long before economic misfortunes were visible, shows that it was not inflation and growth per se, but the growing gap between the nation's project as perceived by military rhetoric on one hand and real developments on the other, that was the fundamental issue.

In 1970 the results of the national demographic and economic census demonstrated the extent to which inequality in incomes had increased over the past 10 years. The figures were so striking that they generated a debate in the press that became a major national issue. Despite harsh press censorship the regime could not prevent the debate from occurring, since management, both public and private, could not plan ahead without credible census figures. In any case, there was no need to spell the conclusions out as they had been felt, seen and lived by every citizen except those in the upper 2 per cent income bracket. Soon afterwards several more standard of living indicators were published and demonstrated declining per capita consumption of essential commodities and staple food and increasing infant mortality and epidemics. Indeed in 1972, when economic growth was at its highest (11 per cent), even President Medici felt moved in a public speech to utter the phrase that may identify him historically in the future: "Brazil is doing better than ever but Brazilians are doing worse than ever."
More graphic than the most sophisticated analysis by a political scientist, President Medici's statement shows the extent to which State and Nation, the government and the people, had become separated under military rule in Brazil. Because the hierarchical structure of the army makes it difficult for officers to make their opinions public unless authorised by their superiors, very little is known about the reactions of army officers to the facts made public in 1971-72. Very little also is known about the clashes within the army which led to Geisel, instead of one of Medici's own men, being appointed incoming president. However, both from widespread rumours and from what one may deduce from public speeches by senior government ministers on economic and welfare issues, it seems that many high-ranking officers shared the bitter feeling that the army had played the role of sorcerer's apprentice rather than that of guardian and tutor to the nation.

When the minister of finance, Delfim Netto, had produced his "The cake must grow before we may share it" theory in an attempt to neutralise internal opposition within the regime, he was hardly convincing. In fact, even those who may have agreed with the argument itself, thought that the model had to be changed. The selection of Geisel against his predecessor's will was probably less a reflection of a rift within the army than a general shift within it in search of new methods of tutorship. He was not only regarded as a nationalist, but also as Chairman of Petrobras, had been a successful military manager of a large, profit-making state-owned company. It was believed he was not likely to be misled by civilian technocrats as Medici had been by Delfim Netto and his fellow economists.

The pressures of the objective political context as well as of the process of ideological revision within the army also required concessions by the regime in order to allow a higher-even if never very clearly defined-degree of participation by public opinion. In the past 10 years the absence of any political meaning in previous elections and harsh censorship had proved themselves a double-edged knife. Since they had taken over in 1964, the military leaders had never actually stated that they would prevent elections and abolish meaningful political parties. Nor could they have ever admitted the institution of an openly totalitarian regime. The very rationale of their intervention, in terms of their own internal ideology, and not just for external consumption, was that it had been to prevent civilians-the supporters of Goulart-from establishing just such a regime. Moreover, the USA whose participation in helping to stage and trigger off the coup 
was scarcely a secret was still in the mood of Kennedy's Camelot promises and LBJ's Great Society, and could not allow itself to be involved in the creation of an open dictatorship in Latin America in that particular context.

Finally, as the self-appointed tutors of civil society, the Brazilian soldiers included the political education of the masses among their functions. Sometime in the future the Brazilian lower classes would become politically mature enough to participate freely in electoral games like their older brothers in the Anglo-Saxon countries-without ruining the festival.

This helps to explain the inner political contradictions which have prevented the Brazilian military from institutionalising its regime and from adopting as its openly acknowledged ideology and authoritarianism it practises. It also suggests why they never attempted to develop a fascist or Nasserite style of mass mobilisation. As Cardoso points out, the regime is guided by dual principles: the constitutional order which anticipates elections; and the institutional acts which transform the military President into a de facto dictator as long as the political order is perceived to be threatened according to criteria determined by the organs of military security. 4

One of the army's first acts after the 1964 coup had been to purge "subversive elements" from every national institution, such as the courts, schools, government corporations, the congress and local councils, political parties and the army itself. A large number of politically significant citizens, including 92 officers and over 30 generals, were banished (cassados) and lost their political rights. The next step was to force the many pre-coup political parties to merge into two single large ones: ARENA and MDB. Both parties were a creation of the Revolution and were supposed and understood to be faithful and committed to its principles. Although ARENA was labelled the government party and MDB was supposed to play the role of loyal opposition, the identity between the two in practice was believed to be so complete that many members of the congress did not care much to which party they were assigned. 5 Their lack of political substance became so apparent that at every election between 1964 and 1974 (voting being compulsory) electors who really wished to express their opposition to the regime cast blank ballots instead of voting

4 See F. H. Cardoso "Capitalist Development and the State: Bases and alternatives" unpublished paper presented at Cambridge on 18 th December 1976.

5 Since their cration up to the end of the 1960s, Brazilians have sarcastically called ARENA the party of 'Yes' and MDB the one of 'Yes Sir'!
MDB. Indeed, by the 1972 administrative elections blank ballots had become the majority. This meant that the MDB continually lost votes and seats while both loyalists and rural-controlled electors stuck to the rules of the fiction and voted ARENA. This eventually, however, forced MDB to shift from nominal to active opposition. And although it practised studied moderation and did its best not to challenge the legitimacy of the regime or even of military rule, it began increasingly to gain votes again. After Geisel took office in 1974, the very dynamic of its new political course forced MDB to adopt more radical positions, pressing for a liberalisation of the regime and for a return to direct Presidential and State government elections after the end of Geisel's term of office.

\section{Transformations in the hegemonic alliance}

From the time of its assumption of power the military has been faced with a growing contradiction in its class alliance. The original military takeover of 1964 had in effect been a conspiracy between the officer corps and sectors of the national bourgeoisie, with financial support and technical help both from US government and American multinationals. Yet the economic programmes adopted by the military governmentpartly as a result of the doctrines of the National War College (ESG)-have in effect brought into being a new political force: the technocrats and managers of public sector enterprises who have become a powerful fraction of the emerging hegemonic alliance.

In spite of the economic liberalism that provided the ideological cloak for their assumption of office, the generals not only did not dismantle the state-owned sector of the economy during their first decade in office, but were actually driven to strengthen it. By 1975 state enterprises accounted for more than half of public sector investment and more than 30 per cent of total investment. In the same year 56 of the 100 largest Brazilian enterprises were state-owned. ${ }^{6}$ In addition, a degree of state control of the activities of privatelyowned enterprises is ensured by the fact that most of them are indebted to state-owned banks such as BNDE (National Bank For Economic Development).

In sum, the Brazilian military has actually been shaping a new form of state capitalism and creating a new class of public entrepreneurs or, as it is called sometimes, a state bourgeoisie whose interests are far from identical to those of private

6 Cardoso idem 
entrepreneurs. Several authors such as Cardoso, O'Donnel and Sunkel have analysed the role of state intervention in capitalist industrialisation. What I am mainly concerned with here, however, are not the broad contradictions originating from the State's role in assisting capital accumulation by multinationals and to a lesser extent, local entrepreneurs; but a second level of contradictions which prevent the institutionalisation of a stable regime in Brazil.

Whatever its rhetoric, the Brazilian military coup of 1964 in fact amounted to the replacement of a particular alliance of dominant classes which depended on the populist participation of the masses, by a new state and hegemonic alliance which excluded these masses and merely regarded them as a source for capital accumulation. In these circumstances, the maintenance of a liberaldemocratic facade, the creation of sanitized political parties and of the Congress and the holding of elections, have proved to be a time-bomb The military had believed that the de facto exclusion of the former civilian politicians would automatically eliminate politics from the country's life. But while national congressmen and state deputies were despised and labelled the political class (people affected by a civilian disease that had to be tolerated, even if under strict control) in fact political activity was as healthy and vigorous as ever, both within the army itself and through the networks organised around high officials, ministers, chairmen of state-owned companies and banks which Cardoso has referred to as "bureaucratic rings".

By 1971-72 the frictions between different interest groups, both inside and outside the army, had become more acute. The fact that elections lacked any political meaning as well as the increasing censorship of the press was regarded by certain sectors of the power structure as more of a liability than an asset. With political life dispersed and atomised, how was one to know who represented whom? How were decisions to be taken when interests of different economic and regional pressure groups clashed? And as the army, after almost a decade of political rule, began to break into political and entrepreneurial factions, many military men came to realise that behind-the-scenes politics in the military establishment could jeopardise its ability to impose internal consensus through hierarchical rules. Thus, by 1974 when Geisel was inaugurated, the inadequacy of the official ideology was clear, and the need for new institutional solutions was urgently felt. Although the MDB's landslide victory in 1974 elections (only seven months after Geisel's inauguration) was an almost incredible surprise to everybody (including MDB leaders), it had to be tolerated as a tentative step toward these new solutions.

But meanwhile the economic miracle, based mainly on the expansion of durable consumer goods production for the limited market constituted by the new upper middle-class of professionals, technocrats and business executives, had exhausted itself. The internal dynamism of Brazilian political economy required a shift towards capital goods import substitution, which in its turn required additional imports and long term investment: hence both external and internal inflationary pressures. The rise in oil prices, world recession and external inflation were indeed the last straw. But they were not the first and only cause of Brazil's internal economic problems as claimed by the official rhetoric.

Although economic growth has not yet significantly slowed down since the years of the miracle-it dropped only from 11 per cent in 1972 to 8 per cent in 1976-the new economic context has increased friction between the three main actors of the political scene: the state managers, the national entrepreneurs and the multinationals, each one of them related to military groups through its own series of bureaucratic rings.

During 1976 government political and economic discussions became so erratic and contradictory as to suggest that the hegemonic alliance was disintegrating. It soon became evident that Geisel was losing control and was being directly challenged by different opposition groups which included military officers, prepared to resort to active terrorism. In the autumn there began a series of violent terrorist actions such as the bombing of a series of civilian liberal institutions such as the Press and Bar Associations, the kidnap of a bishop, and other events whose main purpose seemed to be to prove Geisel's lack of power or to test his willingness to shift political alliances. Again, the "struggle between the SS and the Wehrmacht".

What SS meant for the minister who coined the metaphor is far from vague. He clearly referred to the unofficial, although well-known army departments created in every Brazilian state after 1968 , specially trained by American advisers to deal with the guerrilla movements through widely known methods. It is frequently alleged that these groups receive finance from both national and multinational corporations. Certainly, most of them became closely associated with, if not controlled by, certain civilian groups. After the virtual annihilation of the guerrilla movement 
which was achieved by 1972 they were not disbanded. As official funding of their activity shrank, private contributions and influence increased. Yet in spite of being unofficial and highly. influenced by civilian interest groups, these military organisations cannot be supposed to be absolutely independent from the higher organs of military security. To varying degrees, in different situations, their actions must be either approved or tolerated by a significant portion of the generals in command.

In this context of political disintegration, the elections of November, 1976, given their local character, were less important in themselves than as a test for the 1978 elections to congress. MDB's victory in 1978 would imply its ability to influence strongly, if not to decide, the outcome of the indirect election of Geisel's successor. But in spite of severe restrictions imposed on MDB's electoral campaign and of Geisel throwing all his presidential resources in support of ARENA, the government vote, at slightly over 50 per cent of the total, can hardly be regarded as a victory.

By January, political unrest in the business community, particularly in the industrialised state of Sao Paulo, grew to a climax. An incredible, almost surrealist debate took place on civilian participation in political life in which almost every participant said exactly the opposite of what might have been expected on the basis of his political past. Former fund-raisers for military terrorist groups became outspoken against torture; well-known opponents of nationalist economic policies criticised the support multinationals received from the Federal Government; the Minister of Industry, Severo Gomes, a former hardliner in Castelo Branco's cabinet, advocated civilian participation in decisions; one of the most prominent members of the national bourgeoisie who had previously supported the regime, Jose Papa Jr., referred to it as "spurious", and Paulo Villares, the owner of one of the largest private capital goods industries that has most benefited from recent economic policies, labelled Geisel a communist.

Any comprehensive interpretation of such a surprising and contradictory debate is impossible. It seems clear, however, that the hegemonic alliance is deeply shaken, if not broken, and that not one of its political partners is able to produce an ideology or an institutional rearticulation of the regime which could plausibly be put forward as the expression of the nation's general interests.

In February, Geisel asked his old friend and political partner, Severo Gomes, to submit his resignation. And although no reason was stated for his removal it seems clear that it was intended mainly as a warning that the debate should stop. Then in April, Geisel carefully manoeuvred MDB into a position where it had little alternative but to vote against a relatively minor constitutional amendment, causing its rejection by the congress. On this pretext congress was suspended and the Constitution was altered by decree, mainly to modify electoral procedures in such a way as to make it almost impossible for members of the MDB to gain seats in congress or to obtain access to executive positions as state governors or mayors of municipalities.

This last act is nothing but a poor repetition of the previous authoritarian responses to political conflicts, made possible by the dual principles within the regime referred to by Cardoso. But the present crisis seems to be far more deep and complex than those of 1965,1968 and 1969. Although the immediate origins of the present crisis, like the previous ones, can be related to the incapacity of the hegemonic alliance to produce a clearly defined political formula reflecting its pact of domination, what is new is the increase in conflict within the pact itself.

The failure of Geisel's New Deal seems to have undermined the military elite's belief in its ability to accomplish its tutorial mission. A recent manifesto signed by over 60 colonels demanded the return of the armed forces to their barracks, their main argument being that "the army as an institution was being spoiled by its participation in politics". A series of interviews with unnamed generals published by a leading Sao Paulo newspaper suggests that an intense debate is taking place among bewildered army commanders.

The civilian camp is just as agitated and the overall result of Geisel's constitutional amendment has been to create a surprisingly broad campaign for a new constituent assembly. Even more surprising is the large number of ARENA leaders supporting the proposal. The growing rate of inflation and the deflationary measures it will sooner or later require are certainly not likely to ease the frictions and conflicts which have increased over the past two or three years.

Before 1964 the Brazilian ruling classes blamed the plight of the country on the ignorant masses, populism and foreign subversion. After the collapse of the populist pact the military regime purported to eliminate the masses from the political scene. The only thing that was in reality eliminated was the dominant classes' scapegoat for the country's ills. Thirteen years later the masses are still there, poorer and more oppressed than ever. But they are not the same political 
quantity as they used to be. Formerly, they may have represented a known cost to the ruling class for the limited concessions they were able to demand, or a risk to them which could be calculated; but in any event, a known figure. Today, they have become a mystery, an unknown and feared potential for rulers who neither know how to deal with them nor how to include them in their calculations. Given these conditions, widespread and growing claims for a freely elected constitutional assembly sound almost fairytalelike, and further events are hardly predictable. However, as ARENA's senator Daniel Krieger said in February, "No country can live for ever with an undefined regime".

What options seem likely to be available in Brazil? Probably the Mexican model of institutionalised revolution with its velvet glove seldom revealing its authoritarian iron fist is the dream of most of Brazil's ruling ideologists. But if it could not be achieved in 1964 it seems even more remote now, after so many army officers have spent 13 years tasting, or expecting to taste, the benefits of political and economic power. It is not impossible though, and Geisel's frustrated New Deal, with its appeal for the "creative imagination of politicians" in 1975, may be interpreted as a first attempt in that direction. The transition might be signalled by Geisel selecting, not a four star active General, but a retired one or even a civilian to succeed him. And a new regime based on controlled cooption rather than the present violent suppression of the masses might begin to emerge.

On the other hand, given the growing dissatisfaction within the army, the ideological ebullience among mid-ranking officers and the loss of prestige of ESG doctrine, a leftwards movement cannot be excluded. The doctrines of ESG were originally elaborated under the pressure of the cold war. They rested on the twin principles of development and national security according to which economic development was viewed as a necessary condition of Brazil's participation in the defence of Western civilisation against the red threat. After the Cuban revolution and its claim to turn the Andes into Latin America's Sierra Maestra by guerrilla warfare, the emphasis shifted from external to internal security. But today, the internal enemy is no longer visible and security sounds little more than rhetoric. In the meantime, if not development, a massive process of economic growth has taken place in conditions that have strikingly revealed how fallacious and harmful growth can be when regarded as an end in itself.

These facts do not go unnoticed by junior and middle-ranking officers. Besides the recent Colonels' Manifesto, it is known that study groups are mushrooming in the officer corps, some of them devoting their attention to a variety of authors ranging from Marx, Althusser and Poulantzas to exiled Brazilian and Latin American social scientists. Thus, a Portuguesestyle intervention cannot be completely excluded. of course this remains a fairly remote possibility, but the political, institutional and ideological confusion of the last three months may increase its chances, as may the regime's frictions with the Catholic Church and with the US government on the questions of human rights and atomic energy.

When President Geisel appeared on television to announce the suspension of Congress, his main argument was that it was controlled by "a dictatorship of the minority". When shortly afterwards 10,000 students marched in central Sao Paulo to demonstrate against the regime, calling for amnesty, free elections and an end to political repression-an event that would have been almost impossible a year or two ago-some hardline military circles began to put forward surrealistic theories about a joint conspiracy by the CIA and KGB to destabilise the government. ${ }^{7}$

Ideology normally contains an element of deliberate mystification, creating a twilight zone between false consciousness and deliberate distortion of reality. But there are also minimum requirements of internal consistency and relation to reality as it is culturally and socially perceived. Nowadays the political rhetoric of all the different sectors of Brazil's ruling classes seems definitely to have exceeded these limits. The crisis of the regime appears so deep and its ability to produce any consistent ideology so limited, that it is easier to see through the regime's ideological formulas and to acquire a better understanding of what the population's interests really are. Under these conditions hopes that political change will bring better conditions for those who have always been excluded may not be just wishful thinking.

\footnotetext{
7 However, I personally do not believe such a massive demonstration, as well as the ones that followed on May 19th, to have been possible without some support from army factions. As a matter of fact there are persistent rumours of the 'Colonels' Manifesto' group having developed into a mo:e organised political faction, calling themselves the Military Movement for Democratic Constituticn. Yet, their initials, Movement for Democratic Constituticn. Yet, the ir initials,
$M M D C$, are as szciated with the Paulista Revolution of 1932, against Vargas.
} 